\title{
CONDIÇÕES HIGIÊNICO-SANITÁRIAS NA PRODUÇÃO DE QUEIJO ARTESANAL PRODUZIDO EM UBERABA - MG
}

\author{
Hygienie sanitary conditions in production of artesanal \\ cheese made in Uberaba - MG
}

\author{
Clenilson Gonçalves dos Santos ${ }^{I}$, Emiliane Andrade Araújo Naves ${ }^{*}$, Aline Dias Paiva ${ }^{2}$, \\ Priscila C. B. Vianna ${ }^{2}$, Fernanda T. Toloi ${ }^{2}$
}

\begin{abstract}
RESUMO
O queijo artesanal é um dos mais antigos queijos produzidos no Brasil e desempenha importante papel econômico e sociocultural nas regiões produtoras. $\mathrm{O}$ queijo é fabricado com leite cru, o que gera maior preocupação com as boas práticas de fabricação, pois há risco de exposição do consumidor a agentes patogênicos e/ou suas toxinas. Nesse contexto, esse estudo teve por objetivo realizar o diagnóstico sanitário do queijo artesanal produzido no município de Uberaba-MG. Foram selecionados 15 produtores, aos quais foi aplicado um questionário para avaliação das condições higiênico-sanitárias das instalações e do processamento dos queijos, bem como do nível de conhecimento dos produtores sobre a legislação e boas práticas de fabricação. Foram realizadas análises microbiológicas da água, do leite e do queijo de seis das propriedades analisadas. Os resultados apontam que $87 \%$ produtores entrevistados não usavam o "pingo" na fabricação do queijo e comercializavam o queijo com média três dias após a produção, o que caracteriza descumprimento da legislação vigente. Além disso, nenhuma das propriedades realizava a cloração da água, o que pode comprometer a qualidade microbiológica do produto. A pesquisa ainda apontou que $46 \%$ dos produtores desconheciam quais são as prioridades para solicitar a regularização da queijaria junto ao Instituto Mineiro de Agropecuária (IMA). Em relação às análises microbiológicas pode-se afirmar que a maioria dos parâmetros avaliados esteve acima dos limites estabelecidos pela legislação vigente. Dessa forma, concluiu-se que há desconhecimento dos produtores sobre a legislação
\end{abstract}

1 Instituto Mineiro de Agropecuária (IMA), Uberaba, MG, Brasil.

2 Universidade Federal do Triângulo Mineiro (UFTM), Instituto de Ciências Tecnológicas e Exatas (ICTE), Av. Randolfo Borges Júnior, 1250, Univerdecidade, 38064-300, Uberaba, MG, Brasil. E-mail: emilianeandrade@yahoo.com.br

* Autor para correspondência.

Recebido / Received: 30/06/2017

Aprovado / Approved: 08/11/2017 
e há evidente necessidade de capacitação desses produtores em boas práticas de fabricação.

Palavras-chave: leite cru, qualidade microbiológica, produtores rurais, legislação.

\begin{abstract}
The Artisanal cheese is one of the oldest cheeses produced in Brazil, and plays an important economic and sociocultural role in the producing regions. The cheese is made from raw milk, which generates greater concern regarding the good manufacturing practices, since there is a risk of consumer exposure to pathogens and/or their toxins. In this context, this study aimed to perform the sanitary diagnosis of artisanal cheese produced in the city of Uberaba-MG. Fifteen producers were selected, and a questionnaire was applied to evaluate the hygienic-sanitary conditions of the facilities and the cheese processing, as well as the knowledge of the producers on the legislation and good manufacturing practices. Microbiological analyzes of water, milk and cheese were performed on six of the selected properties. The results indicate that $87 \%$ of the interviewed producers did not use the "pingo" in cheese production and, on average, they marketed the cheese three days after production, which characterizes non-compliance with current legislation. In addition, none of the properties performs the water chlorination, a behavior that can compromise the microbiological quality of the product. According to the results obtained, $46 \%$ of the producers are not aware of the priorities for requesting the regularization of dairy products at the Institute of Agriculture of Minas Gerais. Regarding the microbiological analysis of artisanal cheese, all the evaluated parameters were above the limits established by current legislation. Therefore, it is concluded that the producers are not aware of the legislation and there is a clear need for training of these producers in good manufacturing practices.
\end{abstract}

Keywords: raw milk, microbiological quality, farmers, legislation.

\section{INTRODUÇ̃̃̃O}

O queijo Minas artesanal é um dos mais antigos queijos produzidos no Brasil, sendo considerado uma tradição centenária do estado de Minas Gerais (MARTINS et al., 2015; CASTRO et al., 2016). A produção de queijo Minas artesanal desempenha importante papel econômico e sociocultural nas regiões tradicionais produtoras devido à geração de renda e fixação do homem no campo (DORES; FERREIRA, 2012). Esses fatores levaram as autoridades competentes a considerar o queijo Minas artesanal patrimônio imaterial de Minas Gerais e possuir certificado de indicação geográfica de acordo com cada uma das sete regiões tradicionais produtoras destes queijos que são Araxá, Campo das Vertentes, Canastra, Cerrado, Serra do Salitre, Serro e Triângulo Mineiro (CASTRO, 2015).

Até 2013, a comercialização do queijo Minas artesanal era restrita ao estado de Minas Gerais. Com a publicação da Portaria $n^{\circ} 1305$, de 30 de abril de 2013 (MINAS GERAIS, 2013a), o queijo Minas artesanal passou a ser comercializado em todo o território nacional, desde que atendesse às exigências sanitárias.

O queijo Minas artesanal é um queijo 
fabricado a partir de leite cru em diversas regiões do estado de Minas Gerais (ANDRADE et al., 2014). O uso do leite cru como matériaprima gera certa preocupação em termos de saúde pública, pois falta de condições higiênico-sanitárias satisfatórias podem ocorrer desde a ordenha até o armazenamento do produto final, comprometendo a qualidade e expondo o consumidor a agentes patogênicos, como Staphylococcus aureus, Escherichia coli, Salmonella spp, Listeria monocytogenes, Brucella abortus e Mycobacterium bovis (PASSOS et al., 2009).

Para a regularização da produção artesanal de queijo, a Lei Estadual 19.476 de 2011 (MINAS GERAIS, 2011), conhecida como Lei da Agroindústria Familiar dispõe sobre a habilitação sanitária necessária para o estabelecimento agroindustrial rural de pequeno porte no estado. Assim, o produtor necessita atender à habilitação sanitária cumprindo todas as etapas estabelecidas junto ao Instituto Mineiro de Agropecuária (IMA), as quais envolvem pontos importantes como o exame da saúde dos trabalhadores, regularização da vacinação do rebanho, participação em cursos de boas práticas de fabricação do queijo e adequação da infraestrutura local, atendimento à legislação vigente sobre os padrões físico-químicos e microbiológicos para queijo Minas artesanal (MINAS GERAIS, 2013 b), dentre outros.

A habilitação sanitária está condicionada à prévia inspeção e fiscalização sanitária do estabelecimento pelo IMA. Os estabelecimentos agroindustriais rurais de pequeno porte cadastrados no IMA são registrados, relacionados ou certificados quando cumprem, na totalidade, as obrigações assumidas (SALES, 2015).

Nesse contexto, o objetivo principal deste trabalho foi avaliar as condições higiênico-sanitárias do queijo artesanal produzido no município de Uberaba por produtores que almejam o cadastramento pelo IMA para obtenção da habilitação sanitária. Além do diagnóstico sanitário, verificou-se também in loco quais as maiores dificuldades encontradas pelos produtores, no intuito de se adequarem à legislação sanitária para obtenção do registro junto ao IMA.

\section{MATERIAL E MÉTODOS}

A pesquisa foi realizada em seu primeiro estágio com a realização de uma entrevista estruturada in loco envolvendo 15 produtores de queijo artesanal do município de Uberaba. Esses produtores foram selecionados com base no interesse de cadastramento pelo IMA. É importante ressaltar que na região tem-se apenas quatro produtores de queijo Minas artesanal registrados pelo IMA, considerando um total de 25 produtores de queijo em Uberaba, o que justifica a ocorrência desse estudo. Nessa pesquisa, utilizou-se o questionário apresentado por Pinto (2004), em que foram avaliadas as condições higiênico-sanitárias das instalações e da produção dos queijos e o nível de conhecimento dos entrevistados sobre a legislação e boas práticas de fabricação. O projeto foi aprovado pelo Comitê de Ética em Pesquisa, da Universidade Federal do Triângulo Mineiro, em 24 de agosto de 2016, sob o número 1.692.963.

A partir do levantamento da entrevista estruturada foi calculada a frequência de resposta dos produtores para os itens avaliados visando avaliar as condições de processamento do queijo artesanal produzido. Após aplicação do questionário, seis propriedades tiveram interesse na continuidade da segunda parte do estudo, que contemplou as análises microbiológicas da água, do leite e do queijo.

Em cada propriedade rural foram coletados $100 \mathrm{~mL}$ da água utilizada na queijaria, utilizando frascos de vidro estéreis, e $100 \mathrm{~mL}$ de amostras do leite cru, coletadas antes do início da fabricação do queijo artesanal. As amostras de queijo artesanal foram coletadas 1 dia após a fabricação. Todas as amostras 
foram imediatamente transportadas ao Laboratório de Processos Tecnológicos da UFTM, em caixas isotérmicas e mantidas sob refrigeração até o início das análises, as quais foram realizadas no mesmo dia das coletas.

As amostras de água foram coletadas das torneiras dos locais de produção dos queijos e foram avaliadas quanto à contagem de coliformes a $35{ }^{\circ} \mathrm{C}$ e a $45{ }^{\circ} \mathrm{C}$ e quanto à contagem de bactérias heterotróficas (BRASIL, 2003). O leite cru destinado à produção do queijo foi coletado do latão antes da adição do coalho e avaliado quanto à contagem de bactérias totais, utilizando ágar padrão para contagem (ACUMEDIA, Lansing, Michigan, USA), com incubação a $35{ }^{\circ} \mathrm{C} / 48$ horas (BRASIL, 2003).

$\mathrm{O}$ queijo foi avaliado quanto à contagem de coliformes a $35^{\circ} \mathrm{C}$ e a $45^{\circ} \mathrm{C}$, contagem de Staphylococcus aureus, além da análise da presença de Salmonella spp. e Listeria monocytogenes. Para detecção de Salmonella spp. e Listeria monocytogenes, as amostras de queijo foram encaminhadas, sob refrigeração, para laboratório terceirizado, prestador de serviço, localizado na cidade de Uberlândia-MG.

Para o preparo das amostras para as demais análises microbiológicas, $25 \mathrm{~g}$ de queijo foram diluídos em $225 \mathrm{~mL}$ de citrato de sódio (SYNTH, Diadema, SP, Brasil) a $2 \%(\mathrm{~m} / \mathrm{v})$ e homogeneizadas em stomacher por 1 minuto. Para análise de coliformes a $35{ }^{\circ} \mathrm{C}$ foram realizadas diluições decimais e plaqueamentos em Agar Cristal Violeta Vermelho Neutro Bile (KASVI, Curitiba, PR, Brasil); as placas foram incubadas a $36{ }^{\circ} \mathrm{C}$ $+1{ }^{\circ} \mathrm{C} / 24$ horas. A confirmação da presença de coliformes a $35^{\circ} \mathrm{C}$ foi feita por meio da inoculação das colônias suspeitas em caldo verde brilhante bile $2 \%$ (KASVI, Curitiba, PR, Brasil) e posterior incubação a $36+1{ }^{\circ} \mathrm{C}$. Para a contagem de coliformes a $45^{\circ} \mathrm{C}$ inoculou-se colônias suspeitas em caldo Escherichia coli (EC) (SIGMA ALDRICH, St. Louis, MO, USA) e posterior incubação em temperatura seletiva de $45{ }^{\circ} \mathrm{C} / 24$ horas em banho-maria com agitação ou circulação de água. Após a incubação, observou-se a turvação do meio de cultura e a formação de gás nos tubos de Durhan. Os resultados foram expressos em UFC/g (BRASIL, 2003).

Para as análises de $S$. aureus, foi utilizado o Petrifilm 3M - Rapid S. aureus (RSA) Count Plate (Sumaré, SP, Brasil), de acordo com os procedimentos determinados pelo fabricante.

Com relação à análise dos dados do trabalho, a partir do levantamento da entrevista estruturada foi calculada a frequência de resposta dos produtores para os itens avaliados para que pudesse ter conhecimento da realidade das condições de processamento dos produtores de queijo artesanal da cidade de Uberaba-MG. Já as análises microbiológicas foram realizadas em duplicata e em três repetições. Foram obtidas as médias e realizada uma estatística descritiva, mediante comparação com os valores preconizados na legislação vigente.

\section{RESULTADOS E DISCUSSÃO}

A maioria das propriedades rurais avaliadas $(67 \%)$ apresentou produção de leite diária de até 100 litros e produção de até 5 queijos por dia em $53 \%$ das propriedades. A produção diária de leite é um dos pontos que limita o incremento da fabricação de queijo, pois a maior parcela dos produtores possui rebanhos pequenos e com práticas de manejo ultrapassadas, mantendo animais de baixa produtividade e sem manejo adequado das pastagens, entre outros. Foi também possível constatar que $53 \%$ dos produtores têm mais de dez anos de experiência em sua atividade, sendo que apenas $13 \%$ dos produtores estão na atividade há mais de 30 anos, resultado diferente do observado por Pinto (2004), que relatou que $50 \%$ das propriedades avaliadas produziam o queijo Minas artesanal do Serro há mais de 30 anos. 
Os produtores comercializavam o queijo ainda fresco, em média três dias após a produção, não respeitando o tempo de maturação de 22 dias estabelecido pela Portaria $n^{\circ} 1305 / 2013$ (MINAS GERAIS 2013a). Segundo Costa Júnior et al. (2009), em avaliação do queijo Minas artesanal da Serra da Canastra, o que se observa na prática é a comercialização e o consumo com poucos dias ou até mesmo logo após a fabricação dos queijos. O consumo do queijo fresco pode oferecer risco à saúde, pois o período de maturação contribui significativamente para a redução dos patógenos presentes no queijo logo após sua produção (MARTINS et al., 2015).

Com relação à fabricação do queijo, em $80 \%$ das propriedades quem faz o produto é o proprietário. Destes produtores, $60 \%$ possuem pelo menos segundo grau completo e são esses os produtores com maior abertura para as questões de adequação das queijarias. Esse resultado aponta uma relação entre o nível de escolaridade e a conscientização do produtor quanto à necessidade de adequação da queijaria para a produção de um queijo de qualidade.

A maioria dos produtores de queijo artesanal de Uberaba (73\%) nunca participou de treinamentos ou cursos sobre produção de queijo. Em contrapartida, quase metade desse grupo considera-se adequado à legislação sanitária para produção de queijo Minas artesanal, demonstrando assim o desconhecimento sobre as exigências legais de sua atividade. Em contradição com o estudo de Pinto (2004), em que $64,5 \%$ dos produtosempre participam de reuniões de associações de produtores e $100 \%$ se consideraram inadequados à legislação. A falta de treinamento reflete diretamente na qualidade do produto final. A capacitação dos produtores, principalmente em boas práticas de fabricação, muito contribui para as adequações necessárias da queijaria, além de transmitir conhecimentos ao manipulador sobre as condições higiênico-sanitárias ideais para a produção de queijo.

A maior parte dos produtores $(80 \%)$ demonstrou interesse em se adequar à legislação sanitária, porém $46 \%$ desses mesmos produtores desconhecem totalmente quais são as prioridades para solicitar a regularização da queijaria junto ao IMA. No estudo realizado por Pinto (2004), 100\% dos produtores tinham interesse nas adequações e a maior parte enumerou a falta de recursos e o desconhecimento do que precisaria ser feito, como principais dificuldades para essa adequação.

Quanto à avaliação das condições da queijaria, das 15 propriedades participantes do estudo, 27\% possuíam edificações de queijaria destinadas à produção de queijo artesanal, porém, fora dos padrões exigidos pela Lei estadual $n^{\circ} 19.467$, de 11 de janeiro de 2011 (MINAS GERAIS, 2011). Na maioria das propriedades avaliadas $(60 \%)$ o queijo era produzido nas cozinhas das residências e em $13 \%$ das propriedades visitadas, o queijo era produzido na pia do próprio curral, onde também são deixados os utensílios utiliza dos na produção dos queijos. Oliveira (2010), em seu estudo na microrregião do Campo das Vertentes, constatou que $93 \%$ das propriedades possuíam as instalações da queijaria exclusivas para a produção do queijo, 4\% o produziam na residência e $3 \%$ em área sem delimitação alguma.

Foram observadas várias práticas nocivas à qualidade do produto final, como acondicionamento do leite em tambores para coagulação expostos diretamente ao sol, queijos sendo produzidos e maturados em ambiente aberto, expostos a várias fontes de contaminação. Foi evidenciada a presença de animais domésticos nas adjacências do local de produção de queijos em 93\% dos estabelecimentos, índice próximo ao apurado por Pinto et al. (2009) na região do Serro, onde $97 \%$ das propriedades avaliadas, tinham presença de animais nas imediações das queijarias, resultando em fonte potencial 
de contaminação.

Quanto à água de consumo, todos os produtores possuíam caixas d'água como reservatório e em boas condições de conservação, porém em nenhuma das propriedades era realizada a cloração da água, sendo que $47 \%$ desses possuíam como fonte de água o poço artesiano. Oliveira (2010) relata que no Campo das Vertentes, $70 \%$ das queijarias são abastecidas com água proveniente de nascentes e apenas $4 \%$ dos produtores cloravam a água.

Sobre a saúde dos manipuladores, $40 \%$ responderam que realizavam exames de saúde periódicos. Durante a produção do queijo verificou-se que apenas dois dos manipuladores entrevistados faziam uso do vestuário completo durante a produção do queijo. A parcela dos produtores que utilizam até quatro itens do vestuário apropriado para a manufatura do queijo artesanal são aqueles produtores que já participaram de treinamentos sobre produção de queijos e boas práticas de fabricação. Pinto et al. (2009) observou que no Serro a maioria dos manipuladores tinham consciência da importância dos equipamentos de proteção, porém não faziam uso correto.

Apenas 33\% dos produtores faziam uso das peneiras de plástico, como recomendado pela legislação, embora a maioria dos produtores $(69 \%)$ realizasse a coagulação do leite em tambores plásticos não apropriados para esse fim. Oliveira (2010), em seu estudo no Campo das Vertentes, relatou que $57 \%$ dos produtores utilizavam tambores plásticos, o que representa uma prática inadequada, uma vez que estes tambores não permitem a higienização adequada.

Com relação à etapa de agitação da massa verificou-se que $40 \%$ dos manipuladores de queijo artesanal faziam uso de espátula de metal, porém $47 \%$ ainda utilizavam espátulas em madeira, o que não é permitido pela Portaria IMA n ${ }^{\circ}$ 518, de 14 de junho de 2002 (MINAS GERAIS, 2002). Pinto et al. (2009) mostrou que a espátula de madeira estava presente em $97 \%$ das propriedades avaliadas. Para a dessoragem, a maior parte dos produtores $(73 \%)$ utiliza o tecido volta ao mundo, prática semelhante àquela observada por Oliveira (2010) no Campo das Vertentes.

Em relação às bancadas de manipulação, $67 \%$ das propriedades visitadas possuíam bancadas em ardósia. Todos os produtores utilizavam formas de materiais permitidos pela legislação, que possibilitam uma higienização adequada, sendo $93 \%$ formas de plástico e $7 \%$ de alumínio.

De acordo com os produtores de queijo artesanal entrevistados por Galinari (2014), os novos utensílios exigidos pela legislação em detrimento aos de madeira, não contribuem para a melhoria do produto, pois afetam o sabor e textura tradicionais.

Dos processos de limpeza e sanitização verificou-se que $67 \%$ dos produtores de queijo artesanal realizavam uma pré-lavagem de todos os materiais e utensílios diretamente relacionados com o processo de produção, utilizando água, depois água e detergentes na etapa de limpeza e aplicavam sanitizantes, como água sanitária, porém sem seguir as orientações do fabricante. Na entrevista, um único produtor alegou usar apenas água quente, pois segundo o mesmo, o uso do detergente faz seu produto deteriorar. Dados semelhantes foram obtidos por Pinto et al. (2009), porém com resistência ao uso de solução clorada por interferir na qualidade do produto final, de acordo com alguns produtores da região do Serro.

A maioria dos produtores (87\%) de queijo artesanal de Uberaba, não usa o "pingo" e metade desses desconhece o termo quando questionados sobre este item na entrevista. Mesmo nas regiões de maior tradição na produção do queijo artesanal, nem todos os produtores fazem uso desse fermento natural no processo. No Campo das Vertentes foi observado que apenas 3\% dos produtores utilizavam o pingo (OLIVEIRA, 2010). O uso do 
pingo é prática comum em pelo menos quatro das sete tradicionais regiões produtoras de queijo artesanal. Porém, não existem estudos científicos comprovando a necessidade do uso desse fermento, pois qualquer fermento microbiano poderá iniciar uma fermentação, desde que o mesmo contenha maiores concentrações de culturas daquelas contidas no meio onde será adicionado (PAIVA et al., 2016). É importante ressaltar que a Portaria 1305 de 2013 considera o uso do pingo como uma diretriz importante na produção do queijo. Assim, percebe-se uma discordância desses produtores com o preconizado na legislação (MINAS GERAIS, 2013a).

Dos produtores entrevistados no presente estudo, $60 \%$ realizavam a prensagem manual com auxílio do tecido volta ao mundo na própria forma.

Todos os produtores de queijo artesanal entrevistados faziam uso do coalho industrializado líquido, porém em proporções variadas. Os produtores que usam as menores proporções de diluição do coalho alegam que, seguir a medida instruída pelo fabricante deixa o queijo com sabor alterado. Em contrapartida, as diluições menores levam a um maior tempo de coagulação e consequente multiplicação de bactérias indesejáveis que comprometem a qualidade do produto final. Em média, o tempo de coagulação seguindo a recomendação do fabricante é de 40 minutos, porém foram relatados tempos extremos de até 3 horas usando diluições menores.

Uma proporção quase igual de produtores utiliza a salga seca na superfície do queijo (47\%) ou adicionam o sal na coalhada (53\%). Sobre a embalagem dos queijos foi constatado que $80 \%$ das propriedades vendem os queijos embalados em sacos plásticos e $20 \%$ não embalam o queijo artesanal para comercialização.

Em $60 \%$ das propriedades os produtores afirmaram que seus produtos não possuem rastreabilidade, enquanto os demais produtores disseram que podem rastrear seus produtos por possuírem clientes fixos, porém sem demonstrar nenhum sistema que dê embasamento técnico a essa afirmação.

Quanto à análise microbiológica, os resultados da contagem microbiana nas amostras de água, leite e queijo são apresentados na Tabela 1. Os níveis de contaminação, quando comparado ao exigidos pela Portaria $n^{\circ} 1309 / 2013$ (MINAS GERAIS, 2013b) para produção do queijo Minas artesanal, apresentaram-se acima dos parâmetros estipulados, apresentando, nesse estudo, apenas alguns parâmetros em conformidade.

Todas as amostras de água analisadas $(\mathrm{n}=6)$ apresentaram inconformidade para as contagens de coliformes a $35^{\circ} \mathrm{C}$ e a $45^{\circ} \mathrm{C}$, sendo observada a presença de tais bactérias, enquanto a legislação preconiza ausência de coliformes em $100 \mathrm{~mL}$ de água analisada. Destas amostras de água, 66,6\% apresentaram contagem em placa de bactérias mesófilas aeróbias de acordo com a legislação (MINAS GERAIS, 2013b), que preconiza máximo de $5 \times 10^{2} \mathrm{UFC} / \mathrm{mL}$.

Apesar de todas as propriedades possuírem reservatórios em bom estado e $47 \%$ possuírem poço artesiano como fonte de água, nenhuma faz a cloração da água utilizada, o que resolveria boa parte dessa contaminação. Resultados semelhantes foram obtidos por Oliveira (2010), em avaliação do queijo Minas artesanal do Campo das Vertentes, em que $100 \%$ das amostras de água apresentaram contaminação por coliformes a $35^{\circ} \mathrm{C}$ e $45^{\circ} \mathrm{C}$, e apenas $20 \%$ apresentaram resultados satisfatórios para mesófilos aeróbios.

A falta de cloração da água é fator determinante nessas contaminações apresentadas, uma vez que mesmo os produtores que empregam boas práticas de fabricação não conseguem produzir um queijo que ofereça segurança microbiológica ao seu consumidor final, ao fazer uso de água não potável na manipulação. Esse fato reflete a situação da população rural brasileira, em que quase $67 \%$ captam água de fontes alternativas, geral- 
Tabela 1 - Resultados das análises microbiológicas das amostras de água, leite e queijo

\begin{tabular}{|c|c|c|c|c|c|c|c|}
\hline \multicolumn{8}{|c|}{ Propriedades } \\
\hline Análises & Legislação & 1 & 2 & 3 & 4 & 5 & 6 \\
\hline \multicolumn{8}{|l|}{ Água } \\
\hline $\begin{array}{c}\text { Heterotróficas } \\
(\mathrm{UFC} / \mathrm{mL})\end{array}$ & Máx. $5 \times 10^{2}$ & $3,8 \times 10^{2 *}$ & $5,5 \times 10^{2}$ & $3,5 \times 10^{2^{*}}$ & $1,2 \times 10^{3}$ & $8,7 \times 10^{1^{*}}$ & $1,4 \times 10^{2 *}$ \\
\hline $\begin{array}{c}\text { Coliformes } \\
\text { a } 35^{\circ} \mathrm{C} \\
(\mathrm{NMP} / 100 \mathrm{~mL})\end{array}$ & $\begin{array}{c}\text { Ausência } \\
\text { em } 100 \text { mL }\end{array}$ & 643 & 663 & 22,3 & 263 & 26 & 556 \\
\hline $\begin{array}{c}\text { Coliformes } \\
\text { a } 45^{\circ} \mathrm{C} \\
(\mathrm{NMP} / 100 \mathrm{~mL})\end{array}$ & $\begin{array}{c}\text { Ausência } \\
\text { em } 100 \text { mL }\end{array}$ & 77 & 22 & 16,7 & 137 & 7 & 13 \\
\hline \multicolumn{8}{|l|}{ Leite } \\
\hline $\begin{array}{c}\text { Contagem } \\
\text { Bacteriana } \\
\text { Total (UFC/mL }\end{array}$ & Máx. $3 \times 10^{5}$ & $2,0 \times 10^{4 *}$ & $1,3 \times 10^{4^{*}}$ & $1,5 \times 10^{4^{*}}$ & $2,1 \times 10^{4 *}$ & $1,6 \times 10^{4 *}$ & $1,8 \times 10^{4 *}$ \\
\hline \multicolumn{8}{|l|}{ Queijo } \\
\hline $\begin{array}{c}\text { Coliformes } \\
\text { a } 35^{\circ} \mathrm{C} \\
(\mathrm{UFC} / \mathrm{g})\end{array}$ & $5 \times 10^{3}$ & $1,1 \times 10^{6}$ & $8,0 \times 10^{4}$ & $8,2 \times 10^{5}$ & $1,5 \times 10^{6}$ & $9,1 \times 0^{7}$ & $1,6 \times 10^{5}$ \\
\hline $\begin{array}{c}\text { Coliformes } \\
\text { a } 45^{\circ} \mathrm{C} \\
(\mathrm{UFC} / \mathrm{g})\end{array}$ & $5 \times 10^{2}$ & $6,8 \times 10^{5}$ & $7,6 \times 10^{4}$ & $1,6 \times 10^{5}$ & $<1,0 \times 10$ & $1,3 \times 10^{5}$ & $9,2 \times 10^{4}$ \\
\hline $\begin{array}{l}\text { Staphylococcus } \\
\text { spp. (UFC/g) }\end{array}$ & $1 \times 10^{3}$ & $3,8 \times 10^{5}$ & $2,5 \times 10^{5}$ & $5,1 \times 10^{4}$ & $2,7 \times 10^{5}$ & $3,4 \times 10^{5}$ & $3,9 \times 10^{5}$ \\
\hline Salmonella spp. & $\begin{array}{c}\text { Ausência } \\
\text { em } 25 \mathrm{~g}\end{array}$ & $A^{*}$ & $\mathrm{~A}^{*}$ & $\mathrm{~A}^{*}$ & $\mathrm{~A}^{*}$ & $A^{*}$ & $A^{*}$ \\
\hline L. monocytogenes & $\begin{array}{l}\text { Ausência } \\
\text { em } 25 \mathrm{~g}\end{array}$ & $\mathrm{P}$ & $\mathrm{A}^{*}$ & $\mathrm{~A}^{*}$ & $A^{*}$ & $\mathrm{~A}^{*}$ & $A^{*}$ \\
\hline
\end{tabular}

*Resultados em conformidade com a legislação vigente (Minas Gerais, 2013b).

A - Ausente; P - Presente.

mente inadequadas para consumo humano e $66,5 \%$ lançam os dejetos em fossas rudimentares, diretamente no solo ou nos cursos d'água (FERREIRA et al., 2016).

Com relação à análise do leite utilizado no preparo do queijo artesanal, todas as amostras apresentaram contagens de bactérias totais abaixo do máximo previsto na legislação atual, que é de $3 \times 10^{5} \mathrm{UFC} / \mathrm{mL}$
(BRASIL, 2016). Resultados diferentes foram reportados por Castro (2015) ao avaliar amostras de leite utilizado na produção de queijo Minas artesanal do Campo das Vertentes, sendo observada média de $9,7 \times 10^{5} \mathrm{UFC} / \mathrm{mL}$. Contagens elevadas de bactérias totais na matéria-prima influenciam diretamente na qualidade final dos queijos produzidos.

A Instrução Normativa (IN) $n^{\circ} 62$, de 
2011 (BRASIL, 2011), redefiniu os novos limites para contagem de bactérias totais em leite, passando para 1 x $10^{5} \mathrm{UFC} / \mathrm{mL}$. Esse novo parâmetro deveria ter entrado em vigor em $1^{\circ}$ de julho de 2016, entretanto a IN 07 , de 3 de maio de 2016, prorrogou esse prazo para mais dois anos, sendo então o parâmetro de contagem bacteriana total mantido em "máximo de 3 x $10^{5} \mathrm{UFC} / \mathrm{mL}$ " até 2018 (BRASIL, 2016).

Os queijos produzidos nas seis propriedades avaliadas apresentaram contagens bacterianas muito acima dos níveis aceitáveis pela legislação vigente para coliformes a $35^{\circ} \mathrm{C}$ (máximo de $5 \times 10^{3} \mathrm{UFC} / \mathrm{g}$ ) e para coliformes a $45^{\circ} \mathrm{C}$ (máximo de $5 \times 10^{2} \mathrm{UFC} / \mathrm{g}$ ). Almeida et al. (2012), em estudo de caracterização do queijo Minas artesanal de Montes Claros, observou que $57,1 \%$ e $28,6 \%$ dos queijos analisados apresentaram contagens de coliformes a $35^{\circ} \mathrm{C}$ e de coliformes a $45^{\circ} \mathrm{C}$ acima do preconizado pela legislação, respectivamente. Garcia (2016), em estudo semelhante e na mesma região, constatou contaminação por coliformes a $35^{\circ} \mathrm{C}$ e a $45^{\circ} \mathrm{C}$ em $89 \%$ das amostras analisadas.

Com relação às análises para Staphylococcus coagulase positivo, a legislação exige máximo de $1 \times 10^{3} \mathrm{UFC} / \mathrm{g}$ (MINAS GERAIS, 2013b). No presente estudo, foi quantificado $S$. aureus por ser o principal representante do grupo dos Staphylococcus Coagulase positiva. De acordo com Rosec et al. (1997), a presença de Staphylococcus coagulase positivo em alimentos atinge em torno de $97 \%$ e aproximadamente $30,5 \%$ são microrganismos enterotoxigênicos, sendo o $S$. aureus a espécie mais frequentemente isolada. S. aureus é encontrado no leite cru e é um dos microrganismos causadores da mastite bovina (ARQUÉS et al., 2015).

A alta contagem de $S$. aureus encontrada nas amostras de queijo analisadas é preocupante, uma vez que a produção de enterotoxina necessária para provocar into- xicação estafilocócica ocorre com valores de $10^{5}$ a $10^{6}$ UFC/g e em pH acima de 5 (CARMO et al., 2002), ou seja, no queijo com alta contagem há a possibilidade de produção de enterotoxina estafilocócica quando a temperatura ambiente estiver acima de $10{ }^{\circ} \mathrm{C}$ (ARQUÉS et al., 2015).

Cruz et al. (2010) analisando amostras de queijo Minas artesanal comercializado em Montes Claros encontraram 68\% de amostras contaminadas com Staphylococcus coagulase positiva. Passos et al. (2009) encontraram $36,6 \%$ das amostras de queijos com contagens acima de $500 \mathrm{UFC/g}$ para $S$. aureus em estudo com queijo Minas frescal conduzido nas cidades de Arapongas e Londrina - PR. Em queijos artesanais da região do Serro, 82,5\% e $100 \%$ das amostras estavam contaminadas com Staphylococcus coagulase positiva, segundo Brant et al. (2007) e Pinto (2004), respectivamente. Resende (2014), em estudo do queijo minas artesanal do Campo das Vertentes, relatou que $70,8 \%$ das amostras apresentaram contagens de Staphylococcus coagulase positiva acima dos parâmetros definidos na legislação.

Em uma das propriedades analisadas foi detectada a presença de Listeria monocytogenes na amostra de queijo analisada e em nenhuma das amostras de queijo foi detectada presença de Salmonella spp. Nesse estudo, pode se afirmar que $100 \%$ das amostras de queijo artesanal estavam em desacordo com o recomendado pela legislação. Fernandes et al. (2011) em estudo semelhante em Rio Paranaíba-MG consideraram $100 \%$ dos queijos analisados como impróprios ao consumo. O trabalho de Garcia (2016) apontou $89 \%$ das amostras de queijo Minas artesanal impróprias para consumo em Montes Claros-MG e Komatsu et al. (2010) ao analisarem queijos artesanais em Uberlândia-MG, encontraram $88 \%$ de amostras em desacordo com as normas.

Dessa forma, pode se afirmar que os 
queijos artesanais estudados são de baixa qualidade, provenientes de uma série de falhas higiênicas em todo o seu processo de produção. Essas contaminações durante todo o processo ocorrem devido ao queijo artesanal ser um produto muito manipulado e exigir higiene e ambiente adequado para a produção de um produto final de qualidade. Assim, torna-se imprescindível o treinamento do manipulador em boas práticas de fabricação. Ademais, os produtores interessados no cadastramento pelo IMA ainda necessitam de muitos esclarecimentos e de importantes readequações estruturais para que possam atender aos requisitos sanitários necessários para o cadastramento pelo IMA.

Após a análise dos resultados obtidos tanto na entrevista estruturada quanto nas análises microbiológicas do queijo artesanal produzido em Uberaba, ficou evidente a necessidade de capacitação dos produtores participantes. Nesse contexto, com objetivo de auxílio inicial a esses produtores que almejam o credenciamento, foi realizada uma palestra para apresentação dos resultados das análises e conscientização da necessidade de melhoria. Na palestra foram abordados os temas necessários para a melhoria das condições higiênico-sanitárias de produção de queijo artesanal com ênfase nas boas práticas de fabricação. Os produtores tiveram conhecimento das inconformidades encontradas, das legislações pertinentes e receberam mais informações sobre os requisitos necessários ao cadastramento das queijarias junto ao IMA.

\section{CONCLUSÕES}

O queijo artesanal produzido na região de Uberaba está fora dos padrões exigidos pela legislação sanitária de queijo Minas artesanal, a qual foi adotada como parâmetro nesse estudo. As elevadas contagens microbianas encontradas podem estar relacionadas ao desconhecimento pelos produtores das boas práticas de fabricação e das legislações pertinentes. Os estabelecimentos produtores de queijos participantes desse estudo não apresentam ainda condições para obtenção de registro e certificação de seus produtos pelo IMA. Muitas falhas foram observadas, principalmente ao que diz respeito à falta de atendimento às condições de higiene recomendadas para o controle sanitário do produto, além de não possuírem infraestrutura adequada. Os resultados obtidos são importantes também para o conhecimento das autoridades competentes de forma que elas possam se mobilizar para o desenvolvimento de um trabalho de conscientização da educação sanitária para reverter essa situação de baixa qualidade microbiológica dos produtos.

\section{AGRADECIMENTOS}

\section{FAPEMIG.}

\section{REFERENCIAS}

ALMEIDA, A. de C. et al. Caracterização da produção de queijo artesanal na região de Montes Claros, norte de Minas Gerais. Acta Veterinaria Brasilica, v. 6, p. 312-320, 2012.

ANDRADE, C. R. G. et al. Propriedades probióticas in vitro de Lactobacillus spp. isolados de queijos minas artesanais da Serra da Canastra - MG. Arquivo Brasileiro de Medicina Veterinária e Zootecnia, v. 66, p. 1592-1600, 2014.

ARQUÉS, J. L. et al. Antimicrobial activity of lactic acid bacteria in dairy products and gut: effect on pathogens. BioMed Research International, v. 2015, p. 1-9, 2015.

BRANT, L. M. F. et al. Avaliação da qualidade microbiológica do queijo de Minas artesanal do Serro-MG. Arquivo Brasileiro de Medicina Veterinária e Zootecnia, v. 59, p. 1570-1574, 2007. 
BRASIL. Ministério da Agricultura, Pecuária e Abastecimento. Instrução Normativa $\mathrm{n}^{\circ} 62$, de 26 de agosto de 2003. Métodos analíticos oficiais para análises microbiológicas para controle de produtos de origem animal e água. Diário Oficial da União, Brasília, DF, 18 set., 2003. Disponível em: <http://www. agricultura.gov.br/sisleg is-consulta/ $>$. Acesso em: 14 nov. 2016

BRASIL. Ministério da Agricultura, Pecuária e Abastecimento. Instrução Normativa $\mathrm{n}^{\circ}$ 62, de 29 de dezembro de 2011. Altera o caput, exclui o parágrafo único e inserir os $\S \S 1^{\circ}$ ao $3^{\circ}$, todos do art. $1^{\circ}$, da Instrução Normativa MAPAn $^{0}$ 51, de 18 de setembro de 2002. Diário Oficial da União, Brasília, DF, 30 dez 2012. Disponível em: <http://www. agricultura. gov.br/>. Acesso em: 14 nov. 2016.

BRASIL. Ministério da Agricultura, Pecuária e Abastecimento. Instrução Normativa $n^{\circ}$ 7, de 03 de maio de 2016. Altera o Art. 1 A tabela 2 do item 3.1.3.1 do Anexo II da Instrução Normativa $n^{\circ} 62$, de 29 de dezembro de 2011. Diário Oficial da União, Brasília, DF, 04 mai., 2016. Disponível em: <http://www. agricultura.gov.br/sislegis-consulta/ $>$. Acesso em: 14 nov. 2016.

CARMO, L. do S. et al. Food poisoning doe to enterotoxigenic strains Staphylococcus present and Minas cheese and raw milk Brazil. Food Microbiology, v. 19, p. 9-14, 2002.

CASTRO, R. D. et al. Lactic acid microbiota identification in water, raw milk, endogenous starter culture, and fresh Minas artisanal cheese from the Campo das Vertentes region of Brazil during the dry and rainy seasons. Journal of Dairy Science, v. 99, p. 1-11, 2016

CASTRO, R. D. Queijo Minas Artesanal fresco de produtores não cadastrados da mesorregião de Campo das Vertentes - MG: qualidade microbiológica e físico-química em diferentes épocas do ano. 2015. $125 f$. Dissertação (Mestrado em Ciência Animal) Universidade Federal de Minas Gerais, Belo Horizonte, 2015.

COSTA JÚNIOR, L. C. G. Et al. Variações na composição de Queijo Artesanal da Serra da Canastra nas quatro estações do ano. Revista do Instituto de Laticínios Cândido Tostes, v. 64 , p. 13-20,2009.

CRUZ, A. L. M. et al. Qualidade microbiológica de queijo artesanal comercializado em Montes Claros, MG. Revista Higiene Alimentar, v. 24, p. 136-139. 2010.

DORES, M. T.; FERREIRA, C. L. L. F. Queijo Minas artesanal, tradição centenária: Ameaças e desafios. Revista Brasileira de Agropecuária Sustentável (RBAS), Viçosa, v. 2, n. 2, p.26-34, 2012.

FERNANDES, R. V. et al. Avaliação físicoquímica, microbiológica e microscópica do queijo artesanal comercializado em Rio Paranaíba-MG. Revista do Instituto de Laticínios Cândido Tostes, v. 66, p. 21-26, 2011.

FERREIRA, D. C. et al. Avaliação de cloradores simplificados por difusão para descontaminação de água de poços em assentamento rural na Amazônia, Brasil. Revista Ciência \& Saúde Coletiva, v. 21, n. 3, 2016.

GALINARI, E. et al. Microbiological aspects of the biofilm on wooden utensils used to make a Brazilian artisanal cheese. Brazilian Journal of Microbiology, v. 45, n. 2, p. 713$720,2014$.

GARCIA, J. K. S. et al. Qualidade microbiológica de queijos frescos artesanais comercializados na região do norte de Minas 
Gerais. Caderno de Ciências Agrárias, v. 8, p. 58-65, 2016.

KOMATSU, R. S. et al. Queijo artesanal comercializado em Uberlândia-MG. Bioscience Journal, v. 26, p. 311-315, 2010.

MARTINS, J. M. et al. Determining the minimum ripening time of artisanal Minas cheese, a traditional Brazilian cheese. Brazilian Journal of Microbiology, vol. 46, n. 1, p. 219-230, 2015.

MINAS GERAIS. Portaria $n^{\circ} 518$, de 14 de junho de 2002. Dispõe sobre requisitos básicos das instalações, materiais e equipamentos para a fabricação do queijo minas artesanal. MINAS GERAIS - Secretaria de Agricultura, Pecuária e Abastecimento de Minas Gerais. Belo Horizonte, 14 de junho de 2002.

MINAS GERAIS. Lei n. 19476, de 11 de janeiro de 2011. Dispõe sobre a habilitação sanitária de estabelecimento agroindustrial rural de pequeno porte no estado e dá outras providências. MINAS GERAIS - DIÁRIO DO EXECUTIVO, Belo Horizonte, p. 11, col. 2, 12 jan. 2011.

MINAS GERAIS. Portaria n. 1305, de 30 de abril de 2013. Estabelece diretrizes para produção do Queijo Minas Artesanal. MINAS GERAIS - DIÁRIO DO EXECUTIVO E LEGISLATIVO, Belo Horizonte, ano 121, n. 80 , p. 26, 1 mai. 2013a. Caderno I.

MINAS GERAIS. Portaria n. 1309, de 14 de maio de 2013. Dispõe sobre os parâmetros e padrões físico - químicos e microbiológicos de produtos de origem animal e água de abastecimento. MINAS GERAIS - DIÁRIO DO EXECUTIVO E LEGISLATIVO, Belo Horizonte, ano 121, n. 89, p. 29, 15 mai. 2013b. Caderno I.

OLIVEIRA, V. J. Da qualidade e organiza- ção da produção ao reconhecimento de região produtora de Queijo Minas Artesanal: a experiência dos produtores da Microrregião Campo das Vertentes-MG. 2010. 205f. Dissertação (Doutorado em Ciência dos alimentos) - Universidade Federal de Lavras, Lavras, 2010.

PAIVA, V. N. et al. Efeito da adição do fermento natural sobre a contagem de bactérias láticas em Queijo Artesanal do serro. Revista do Instituto de Laticínios Cândido Tostes, v. 70, p. 279-285, 2016.

PASSOS, A. D. et al. Avaliação microbiológica de queijos Minas frescal comercializados nas cidades de Arapongas e Londrina - PR. Revista do Instituto de Laticínios Cândido Tostes, v. 69, p. 48-44, 2009.

PINTO, M. S. et al. Segurança alimentar do Queijo Artesanal do Serro, Minas Gerais, em função da adoção de boas práticas de fabricação. Pesquisa Agropecuária Tropical, v. 39, p. 342-347, 2009.

PINTO, M. S. Diagnóstico socioeconômico, cultural e avaliação dos parâmetros físico-químicos do Queijo Artesanal do Serro. 2004. 134 f. Dissertação (Mestrado em Ciência e Tecnologia de Alimentos) - Universidade Federal de Viçosa, 2004.

ROSEC, J. P. et al. Enteroxin production by staphylococci isolated from food in France. International Journal of Food Microbiology, v. 35, p. 213-221, 1997.

SALES, Gilson A. Manual de regularização das agroindústrias familiares. Belo Horizonte: [s.n.], 2015. Manual elaborado pelo Médico Veterinário Gilson de Assis Sales, Gerente de Educação Sanitária e Agroindústria Familiar - IMA - Instituto Mineiro de Agropecuária. 